NBER WORKING PAPER SERIES

\title{
FOOD FOR THOUGHT: THE EFFECTS OF SCHOOL ACCOUNTABILITY PLANS ON SCHOOL NUTRITION
}

\author{
David N. Figlio \\ Joshua Winicki \\ Working Paper 9319 \\ http://www.nber.org/papers/w9319 \\ NATIONAL BUREAU OF ECONOMIC RESEARCH \\ 1050 Massachusetts Avenue \\ Cambridge, MA 02138 \\ November 2002
}

The authors gratefully acknowledge the financial support of the National Science Foundation and National Institutes of Child Heath and Human Development, and thank the U.S. Department of Agriculture for providing us with Virginia school lunch menus. We appreciate the careful research assistance of Mitch Rosenstein and Misty Swain, insights from Kathryn Sucher, and the helpful comments from participants at the 2002 meetings of the American Economic Association. We immeasurably benefited from the first-hand accounts of elementary school nutrition offered by Joseph and Rebecca Figlio. The opinions expressed in this paper do not necessarily reflect those of their employers, funders, or young children, the latter of whom respectfully disagree with the authors' derogatory characterization of "empty calories." We, in turn, blame them for any remaining errors. The views expressed herein are those of the authors and not necessarily those of the National Bureau of Economic Research.

(C) 2002 by David N. Figlio and Joshua Winicki. All rights reserved. Short sections of text, not to exceed two paragraphs, may be quoted without explicit permission provided that full credit, including (C) notice, is given to the source. 
Food for Thought: The Effects of School Accountability Plans on School Nutrition

David N. Figlio

Joshua Winicki

NBER Working Paper No. 9319

November 2002

JEL No: I2

\begin{abstract}
School accountability systems based on high-stakes testing of students have become ubiquitous in the United States, and are now federal policy as well. This paper identifies a previously-unresearched method through which schools faced with potential sanctions may "game the system" in order to have higher aggregate student test scores than might otherwise be warranted. There exists a well-established link between nutrition and short-term cognitive functioning. Hence, we investigate whether school districts exploit this relationship by strategically altering school nutrition menus during testing periods in an apparent attempt to artificially increase student test scores. Using detailed daily school nutrition data from a random sample of Virginia school districts, we find that school districts having schools faced with potential sanctions under Virginia's Standards of Learning (SOL) accountability system apparently respond by substantially increasing calories in their menus on testing days, while those without such immediate pressure do not change their menus. Suggestive evidence indicates that the school districts who do this the most experience the largest increases in pass rates.
\end{abstract}

David N. Figlio

Department of Economics

University of Florida

Gainesville, FL 32611-7140

and NBER

david.figlio@cba.ufl.edu
Joshua Winicki

American Institutes for Research 1990 K Street, NW

Washington, DC 20006-1107

jwinicki@air.org 


\section{INTRODUCTION}

With the passage of the No Child Left Behind Act of 2001 school accountability is now federal law, continuing the recent trend of states implementing significant accountability systems for schools. The federal accountability law requires that all states evaluate schools based on the fraction of students meeting proficiency standards on state curriculum-based examinations. States are required to sanction schools that repeatedly fail to meet their proficiency goals for every subgroup, and federal law requires that part of a school district's Title I funding be used for choice-related transportation and private supplemental services for students in sanctioned schools. Prior to the federal accountability law, state systems ranged from merely presenting school test score comparisons in a public setting to offering school choice or closing schools that do not meet certain performance criteria. These accountability systems invariably place considerable weight on the results of students' standardized test performance. As a result, and indeed, by design, schools are likely to pay closer attention to student test scores.

Schools may respond to this increased attention and threat of sanctions in many different ways. The response presumably desired by policy-makers involves sharpening the focus on academic subjects tested on the examinations. But other responses are possible as well: One possible response involves shaping the test pool—schools may attempt to increase aggregate test scores by reclassifying students into test-excluded categories. Recent papers by Cullen and Reback (2002), Figlio and Getzler (2002) and Jacob (2002) indicate that schools threatened by accountability systems respond by classifying potentially failing students as disabled. Jacob and Levitt (2001) also suggest that teachers may cheat in order to make their students' test scores look better than they should. Schools may also respond by retaining low-performing students in grade to improve aggregate test score measures. 
This paper explores an alternative approach to "gaming" the accountability system. We investigate whether, in addition to reshaping of the test pool, schools respond to accountability systems by artificially improving the learning conditions on test days. One tool at the disposal of school administrators is school nutrition. The link between nutrition and cognitive ability has been well established, and nearly all public schools participate in the National School Lunch Program (NSLP), which provides low-cost, nutritious meals to students. All lunches served in the NSLP are subsidized, but students whose family incomes lie between 130 and 185 percent of the poverty line receive deeper subsidies, and students at or below 130 percent of poverty receive free meals. Since, unsurprisingly, free and reduced-price lunch participation and poor test performance are highly correlated, school nutrition programs reach a disproportionate fraction of the low-performing students in a school, precisely those students whose test scores the school most needs to improve to satisfy accountability provisions. The NSLP's regulations allow for considerable flexibility in fulfilling nutritional guidelines over the course of a school week, as well as substantial flexibility in determining overall caloric counts both on a given date and over the course of a week. Thus, it is possible for school administrators to alter nutritional content from one day to the next or one week to the next.

In this paper we examine how school districts might respond to accountability systems by altering the nutrient content of school lunches around test dates. In particular, we examine changes in the nutritional content during the administration of the standardized tests used for "grading" schools. We use extremely detailed elementary school lunch menus from school year 1999-2000 conducted by the U.S. Department of Agriculture of a random sample of school districts in Virginia and compare nutritional content during days that state-mandated tests were administered to nutritional content on non-test dates. Virginia is an ideal place to study this issue because its accountability system, the Standards of Learning (SOL), has been in place since 1995 
and schools are threatened with sanctions if fewer than 70 percent of students meet minimum proficiency levels. We find positive evidence that nutritional content of school meals is altered on test dates, particularly in districts with at least one "failing", or sanctioned, school. The evidence therefore suggests that districts alter their menus in an attempt to improve student test scores. Moreover, suggestive evidence on pass rates indicates that this approach may be successful.

At first blush, one might question the plausibility of schools using the nutrition margin as a way to improve student test scores. However, there are several reasons to suspect that this may be a plausible and sensible tack to take. First, school lunch programs tend to target precisely the students most "needed" by schools to succeed in the accountability system: School accountability systems generally evaluate schools based on the fraction of students attaining a particular minimum acceptable threshold. The students who do not attain this threshold are overwhelmingly low-income, and thereby eligible for subsidized lunches. And since school meal take-up is unsurprisingly very high among those identified as eligible to participate in the program, the stomachs (and hence, according to the nutrition literature, the minds) of a very large fraction of the marginal students in a school are reached by the school nutrition program.

Second, since schools, or districts, have the technology to carefully track and monitor the nutritive contents of their meal programs, as well as considerable autonomy in menu selection, this is one margin more easily manipulable by the school than most levers that schools might choose to affect student outcomes. Most school food service directors either have degrees in nutrition or have at least been certified by the American School Food Service Association, and are presumably familiar with the links between nutritional content and cognitive performance, so this margin may well be known to most school nutrition decision-makers. 
Moreover, unlike some of the methods of gaming more widely suggested, such as reclassification of students as disabled, school nutrition is much more difficult to audit, and importantly, the higher governmental agency that audits school nutrition is the U.S. Department of Agriculture, rather than the state or federal education authorities implementing an accountability system. School nutrition is therefore a unique policy lever, as there is a disconnect between the authorities ensuring compliance with nutrition policies and the authorities ensuring compliance with education policies. Hence, schools, or districts, have both the ability and the incentive to adjust school meal composition in an attempt to temporarily improve cognitive performance by marginal students.

\section{EATING INTO A TEST: NUTRITION AND COGNITION}

Research examining how nutrition might affect cognitive ability comes in three main categories. First, there is work that links fairly objective measures of nourishment to both learning and growth. This work is largely in developing countries (Pollitt, 1988; Freeman et al, 1980; Jacoby et al, 1996; Chandler et al, 1995), but some domestic work on food insufficiency/insecurity has been recently conducted (Dunifon and Kowaleski-Jones, 2001; Winicki and Jemison, 2003). A second strand of the literature measures the effect of nourishment on behavior and cognition. This work tends to rely on large US datasets (Alaimo et al, 2001; Hicks et al, 1982; Pollitt et al, 1996; Murphy et al, 1998). A third literature estimates the effect that particular nutrients may have on cognitive abilities using scientifically based experiments where small treatment and control groups are evaluated. It is this last strand of research that bears most directly on the present topic.

Several studies find glucose to improve short-term cognitive ability (Benton and Parker, 1998; and Pollitt, Cueto and Jacoby, 1998). The results indicate a substantial and significant 
gain in cognitive ability from the consumption of glucose, or empty calories, which provides a boost in energy. The increased calories consumed enhanced scores on a psychological battery, and on verbal intelligence. Most of the work in this area conducts experiments after an overnight fast; however, recent research (Sunram-Lea et al, 2001) suggests that these results are invariant to time-of-day and fast duration. Though other work has found other key nutrients, particularly iron (Seshadri and Gopaldas, 1989), to improve cognitive ability in the slightly longer term, the only short-term gain in cognitive ability was from consuming empty calories.

Ironically, the accountability provisions introduced by the U.S. Department of Agriculture with regard to the NSLP may aid schools in the evasion of education accountability provisions. The USDA launched a far-reaching reform of the school meals programs after several studies in the early 1990s reported that school meals were not meeting key nutritional goals. This 1993 reform, the School Meals Initiative for Healthy Children (SMI), was intended to improve the nutritional content of school meals. A main component of the SMI was to limit the fat content in a school lunch to no more than 30 percent of total calories, and saturated fat to no more than 10 percent of total calories. Administratively, the SMI also introduced new menu planning systems for food service directors to implement. The new menu planning system allowed for nutritional guidelines to be met over a one-week time period, as opposed to at each meal time, and also encouraged the use of computer technology to assist in charting the nutritional content of a menu cycle.

These two goals of the SMI-increased computer technology in menu planning and nutritional guidelines to be met over a period of a week — facilitated our examination of how nutrient content might change during days that standardized testing occurs. The use of computer technology in menu planning and nutrient analysis gave rise to several software programs and databases for nutritional analysis. The flexibility of a menu meeting the nutrient guidelines over 
a week gave food service directors the freedom to change nutrient content from day to day, which allowed for intra-week variation in nutrient content. This improved technology and increased flexibility facilitates, and allows for, the tracking of nutritive content of school meals from day to day.

\section{EMPIRICAL STRATEGY}

We seek to determine whether schools respond to incentives to alter nutritive content of school lunch menus during testing periods in an apparent attempt to improve short-term cognitive performance of students. Our empirical strategy is to compare the nutritional content of elementary school menus in the days surrounding the SOL testing period for fifth graders. We focus on elementary school lunches because elementary students are afforded fewer meal choices than are students in higher grades (Winicki and Redwood, 2002). Our basic specifications, therefore, seek to identify testing-period effects in a simple school district fixed effects model that implicitly controls for the fact that certain districts consistently offer systematically different types of nutrition than do others. Because SOL testing was conducted over a three-day period during the school year in question, we can compare lunch nutrition content both between weeks as well as within a week for any given school district. We suspect that districts facing potential sanctions by the state accountability system will be most likely to alter their behavior during testing periods. Hence, we amend our empirical strategy to differentiate the estimated responses between districts with threatened schools and those without such schools.

In order to implement this empirical strategy, we require extremely disaggregated school lunch menu data on a daily basis for the times surrounding test implementation. Fortunately, the U.S. Department of Agriculture occasionally requests details on school lunch menus from school districts, and indeed, had requested details on school lunch menus from a random sample of 23 
Virginia school districts during the relevant period for this study in spring, 2000. Table 1 reports the student population by race and free and reduced-price eligible of all districts in Virginia and of the sampled districts. None of the differences between sampled districts and all the districts are statistically significant.

The data collected by the U.S. Department of Agriculture are sufficiently detailed that we can measure with confidence several key nutrients. In addition to caloric content of school lunch menus (the nutrient of interest, given the aforementioned nutrition literature) we can measure several other nutrients which, while likely quite important for long-term growth and development, have not been found to influence short-term cognition. Specifically, we can measure the protein, calcium, vitamin A and vitamin $\mathrm{C}$ content of school lunch menus by day. Regrettably, we are unable to measure the iron content of school lunch menus, so cannot investigate whether schools alter the iron content of lunches to fit testing calendars.

\section{TESTING AND SCHOOL LUNCH MENUS}

A first pass through the descriptive data is informative in order to help fix ideas. The first column of Table 2 reports descriptive statistics over the entire study period for each of the nutrients considered in the analysis. We observe that school lunches in our sample average 817 calories, with 535 milligrams of calcium, 33 milligrams of vitamin C, and $548 \mathrm{RE}$ of vitamin A. On average, 30 percent of calories come from fat, which complies with regulations, and 17 percent of calories come from protein. We observe, however, that there exists considerable day to day variation in these nutrients: For instance, the standard deviation in calories is 220 , and the interquartile range in calories is 203 . This variation is not only across districts: The lowest observed within-district interquartile range in our sample is 108 calories, while the highest observed within-district interquartile range is 355 calories. 
Of course, we are particularly interested in determining whether nutrients vary over the testing cycle. At first blush from the descriptive data, it does not appear that schools alter their nutrient content over this cycle. On average, school lunches contained 815 calories during testing days, as opposed to 812 in the week prior to the test and 806 in the week following the test. A similar lack of an apparent pattern exists for all other nutrients, save vitamin A. In the case of vitamin A, schools average $496 \mathrm{RE}$ during testing periods, as compared to $616 \mathrm{RE}$ the week prior and $539 \mathrm{RE}$ the week after the test.

As mentioned above, however, we suspect that the schools with the greatest incentive to alter their nutritional content to maximize test performance are those threatened with censure by the state of Virginia. The next set of columns in Table 2 present these same comparisons for the districts with at least one school in danger of sanctions. We find that in these districts calories vary substantially over the testing calendar, on average. During testing periods, school lunches average 863 calories, as compared to 761 calories before and 745 calories after the testing period. Other nutritional content, however, appears to be lower during test periods: Vitamin A averages $531 \mathrm{RE}$ during testing but $615 \mathrm{RE}$ before and $672 \mathrm{RE}$ after the testing period, and Vitamin $\mathrm{C}$ averages 34 milligrams during the testing period as opposed to 37 milligrams before and 44 milligrams after the test. Calcium provision appears to increase during test periods for this group of schools: 535 milligrams during testing rather than 523 milligrams before and 492 milligrams after the testing is complete. Fat percentage stays virtually constant over this time frame.

The calorie comparisons differ sharply from the patterns observed in the districts without threatened schools. In these districts, calories are actually somewhat lower during the testing period: 793 calories, rather than 835 calories before the testing period and 834 calories following testing. Less perceptible test-timing-related patterns exist in the case of the other nutrients. 


\section{Fixed Effects Results}

Table 3 presents the results of model specifications in which we control for school district fixed effects. This specification includes the week prior, the week of, and the week after the SOL-test dates. We observe that, just as was seen in the descriptive tables, the fixed effects models tend to find no particular general effect of testing. The closest exception relates to vitamin A, where the estimated effect of testing is negative and statistically significant at around the 20 percent level. Here and throughout the paper, standard errors are nearly identical whether or not we correct the standard errors for potential district-level clustering.

The second panel of Table 3 reports the estimated effects of the testing calendar when this effect is separated for threatened school districts and non-threatened school districts. We report the estimated effects of testing for non-threatened schools, as well as the interaction term between testing and a dummy variable reflecting whether a school in the district is threatened. Because this dummy variable does not vary within a district, its effect is subsumed within the controlled-for district fixed effects and not independently reported.

We observe that the testing calendar is associated with substantial differences among threatened and non-threatened school districts in their apparent caloric responses. While nonthreatened districts are estimated to have reduced calories by $47(p=.09)$ during testing periods, the difference between threatened and non-threatened responses is 140 calories $(p=.01)$. Recalling that during this sample period school lunches averaged 816 calories, this result indicates that testing in threatened schools is estimated to have a 17 percent greater impact on calories than its effect in non-threatened schools.

While calories increase dramatically in the threatened schools relative to non-threatened schools, other nutrients do not see such increases. For instance, threatened schools apparently 
reduce vitamin $\mathrm{C}$ content marginally relative to non-threatened schools during testing periods. Protein content in lunches of threatened schools also falls (though its effect is only statistically significant at the 14 percent level) relative to that of non-threatened schools during testing periods. Consistent with USDA guidelines, fat content remains essentially unchanged in threatened and non-threatened schools during testing periods. The only nutrient estimated to increase during testing periods in threatened schools relative to non-threatened schools is calcium, but this result is only statistically significant at the 30 percent level. In summary, while there exists strong evidence that caloric content of lunches increases with testing, there is no evidence that threatened schools provide more nutritious lunches along other dimensions. These results suggest that school districts threatened with censure by the state accountability system respond by manipulating school nutrition along the dimensions most likely to artificially improve short-term cognitive ability.

As a sensitivity check, we estimated the same model for every other three-week period in February and March 2000 in order to determine whether any other three week period witnessed the same pattern as was observed during the testing period in question. Table 4 presents the results of the calories model for each three-week period, assuming testing began on Monday, just as actually occurred. (On the week of President's Day, we began "testing” on Tuesday, since Monday is a holiday.) As can be seen in Table 4, in no case is the estimated effect of "pseudotesting" greater than around 40 percent of the estimated effect of testing during the actual testing period, and in no case is an estimated positive effect of "pseudo-testing" statistically significant at conventional levels - the most significant an effect seen is the 25 percent level. In two of the six false testing periods, the estimated effect of "pseudo-testing" is negative rather than positive. Therefore, we are more confident that the findings reported above are not due to a fortuitous idiosyncrasy in the data, but are rather due to actual effects of testing. 
Table 5 presents the results of an alternative sensitivity check, in which we in turn drop one school district at a time to gauge whether any one district is driving the results in question. We observe that no one district is responsible for the positive estimated effect of testing. Excluding any given school district could weaken the point estimate on the interaction between testing period and threatened district to as low as 121 calories or as many as 158 calories. But in all cases, the estimated coefficient on this interaction remains very strongly statistically significant and stable in magnitude. (Similarly, the exclusion of any given school district never substantively affects the magnitude or statistical significance of the non-results of the "pseudotesting" exercises reported above.) Therefore, this second sensitivity check only strengthens the argument that the testing effects estimated herein are real.

An alternative explanation for our findings is that schools may recognize that testing periods are stressful for students (and particularly stressful, perhaps, for students in schools facing sanctions) and therefore offer the students their favorite foods as a "reward" on test days. While we cannot definitively rule out this explanation as a possibility, it seems quite unlikely. According to interviews with one school district in our sample, elementary students' favorite meals, as measured by sales, are pizza, cheeseburgers, and tacos, in that order (with pizza as the clear favorite.) However, the likelihood that a school will serve one of these items during the testing period is no greater than the likelihood that they would be served on any given nontesting day. The schools in our sample served one of these items on 35 percent of testing days, as opposed to 34 percent of non-testing days. These schools served pizza on 15 percent of testing days and 16 percent of non-testing days. Hence, the manipulation that we uncover and report above appears to be more subtle than merely offering students the foods they want on test days. 


\section{Is Manipulation Successful?}

Given that school districts with schools that are threatened with sanctions appear to modify their school nutrition during testing periods, the logical next question to ask is whether the districts threatened with sanctions that increase calories the most on test days see the largest gains in test scores. While we have an extremely small sample size, we can at least look for suggestive evidence in response to this question. We therefore regress school fifth grade pass rates on pass rates in the previous year and a measure of calorie differentials during the testing period. We measure this calorie differential as the difference between average calories on test days and average calories on the other days during test week and the weeks immediately before and following the testing days. We limit the analysis to schools in the districts with at least one school threatened with sanctions, because these are the districts that we estimate to be prone to manipulation of school nutrition.

Table 6 presents the results of these regressions for each of the five tests given in the fifth grade. The unit of observation is the individual school, but because the school lunch calorie differential variable varies only at the district level, standard errors are adjusted to correct for district-level clustering. The coefficient reported in the table is the estimated coefficient on the calorie differential variable, which has an average value of 110 among the school districts with threatened schools. We observe that the estimated effect of calorie manipulation is positive across all five tests, and is statistically significant, despite the extremely small effective sample size, in the case of mathematics. The estimated effect is significant at the 14 percent level for English and 18 percent for history/social studies, which suggest a general pattern toward effectiveness. The results suggest that school districts changing calories by 110 , the mean amount observed among the districts with threatened schools, experienced increases in mathematics, English and history/social studies pass rates of 11, 6, and 6 percent, respectively, as 
a result of the calorie manipulation. These results should obviously be taken very cautiously, because of the small sample size, but are at least suggestive of the possibility that the threatened school districts that changed calories the most also saw the largest increases in pass rates.

\section{CONCLUSION}

Proponents and critics alike of accountability systems have warned of the incentives to "game the system" that could be embedded in accountability programs. However, the incentives generally discussed tend to be along the lines of resource allocation or student grouping and classification. This paper presents evidence that there are other, less obvious, incentives that schools apparently recognize and act upon. We find significant evidence that schools, particularly those threatened by the accountability system, respond to the policy by providing students with "empty calories" on testing days - calories that have been found by nutritionists to have substantial very-short-term cognitive effects but no long-term benefits. Our results raise the specter that test score gains associated with accountability systems may in part be artifacts of manipulation rather than improved efficiency, particularly for schools on the margin. In addition, the finding of increases in caloric content of school lunches suggests that the recent trend toward increased testing may, in its own small way, further exacerbate America's recent epidemic of childhood obesity. 


\section{REFERENCES}

Alaimo, K, C Olson, E Frongillo, and R Briefel. 2001. "Food Insufficiency, Family Income, and Health in US Preschool and School-Aged Children." American Journal of Public Health. Vol. 91, No. 5.

Benton, D, and P Parker. 1998. "Breakfast, Blood Glucose, and Cognition." American Journal of Clinical Nutrition 67(suppl): 772S-778S.

Chandler, A, S Walker, K Connolly, and K Grantham-McGregor. 1995. "School Breakfast Improves Verbal Fluency in Undernourished Jamaican Children." Journal of Nutrition, pp. 894-900.

Cullen, J and R Reback. 2002. "Tinkering Toward Accolades: School Gaming under a Performance Accountability System," Working paper, University of Michigan.

Dunifon, R, and L Kowaleski-Jones. 2001. "The Effects of Food Insecurity and Food Assistance Programs on Children." Mimeograph.

Figlio, D and L Getzler. 2002. "Accountability, Ability and Disability: Gaming the System?" Working paper, National Bureau of Economic Research.

Freeman, H, R Klein, J Townsend, and A Lechtig. 1980. "Nutritional and Cognitive Development among Rural Guatemalan Children." American Journal of Public Health 70: 1277-1285.

Hicks L, Langham R, Takenaka J. 1982. "Cognitive and Health Measures following Early Nutritional Supplementation: A Sibling Study." American Journal of Public Health 72: 1110-1118.

Jacob, B. 2002. "The Impact of High-Stakes Testing on Student Achievement: Evidence from Chicago," Working paper, Harvard University.

Jacob, B and S Levitt. 2001. "Teacher Cheating," Working paper, University of Chicago.

Jacoby E, S Cueto, and E Pollitt. 1996. "Benefits of a School Breakfast Program among Andean Children in Huaraz, Peru." Food Nutrition Bulletin, pp. 54-64.

Murphy, J. Michael, Cheryl Wehler, Maria Pagano, Michelle Little, Ronald Kleinman, Michael Jellinek. 1998. "Relationship between Hunger and Psychoosocial Functioning in lowIncome Americna Children." Journal of the American Academy of Child and Adolescent Psychiatry 37: 163-170.

Pollitt, E. 1988. "Developmental Impact of Nutrition on Pregnancy, Infancy, and Childhood: Public Health Issues in the United States." In N. W. Bray, ed., International Review of Research in Mental Retardation, Vol. 15. Academic Press. 
Pollitt, E, S Cueto, and E Jacoby. 1998. "Fasting and Cognition in Well and Undernourished Schoolchildren: A Review of Three Experimental Studies." American Journal of Clinical Nutrition 67(suppl): 779S-84S

Pollitt E, M Golub, K Gorman, et al. 1996. "A Reconceptualization of the Effects of Undernutrition on Children's Biological, Psychosocial, and Behavioral Development. Social Policy Representative 10: 1-21.

Seshadri S, and T Gopaldas. 1989. "Impact of Iron Supplementation on cognitive Functions in Preschool and School-aged Children: The Indian Experience." The American Journal of Clinical Nutrition 50: 675S-84S.

Sunram-Lea, S, J Foster, P Durlach, and C Perez. 2001. "Glucose Facilitation of Cognitive Performance in Healthy Young Adults: Examination of the Influence of Fast-Duration, Time of day and Pre-Consumption Plasma Glucose Levels." Psychopharmacology 157: 46-54.

U.S. Department of Agriculture, Food and Nutrition Service, Office of Analysis, Nutrition and Evaluation. 2001. "The School Meals Initiative Implementation Study-Second Year Report." Sameer Abraham, Manas Chattopadhyay, Margrethe Montgomery, Darby Miller Steiger, Lynn Daft, Brooke Wilbraham. Project Officer, Patricia McKinney. Alexandria, VA.

Winicki, J, and K Jemison. 2003. "Food Insecurity and Hunger in Kindergarten Classroom: Its Effect on Learning and Growth." forthcoming in Contemporary Economic Policy.

Winicki, J, and D Redwood. 2002. “Are Competitive Foods Competitive? National School Lunch Program Participation in the Presence of 'Competitive foods'.” Mimeograph. 
Table 1: Descriptive statistics on demographic makeup of districts in Virginia and sample districts.

\begin{tabular}{|c|c|c|}
\hline & Virginia & Sampled district \\
\hline \multicolumn{3}{|l|}{ Percent } \\
\hline $\begin{array}{l}\text { White } \\
\text { Hispanic } \\
\text { African American } \\
\text { Sanctioned school present in district } \\
\text { Free/reduced-price lunches }\end{array}$ & $\begin{array}{r}70.0 \\
2.0 \\
26.6 \\
21.1 \\
35.8\end{array}$ & $\begin{array}{r}74.4 \\
3.1 \\
21.1 \\
30.4 \\
37.4\end{array}$ \\
\hline \multicolumn{3}{|l|}{ Average } \\
\hline $\begin{array}{l}\text { Number of schools in district } \\
\text { Enrollment (from CCD) }\end{array}$ & $\begin{array}{r}13.8 \\
5,803.2\end{array}$ & $\begin{array}{r}10.6 \\
4,157.5\end{array}$ \\
\hline
\end{tabular}

* Note: Racial composition computed from National Center for Education Statistics Common Core Dataset. Number of schools, enrollment, and free/reduced-price computed from Virginia Department of Education data.

**None of the reported means in sampled districts are statistically different than the census of districts in Virginia. 
Table 2: Descriptive statistics on nutritive content of elementary school lunches in Virginia public schools

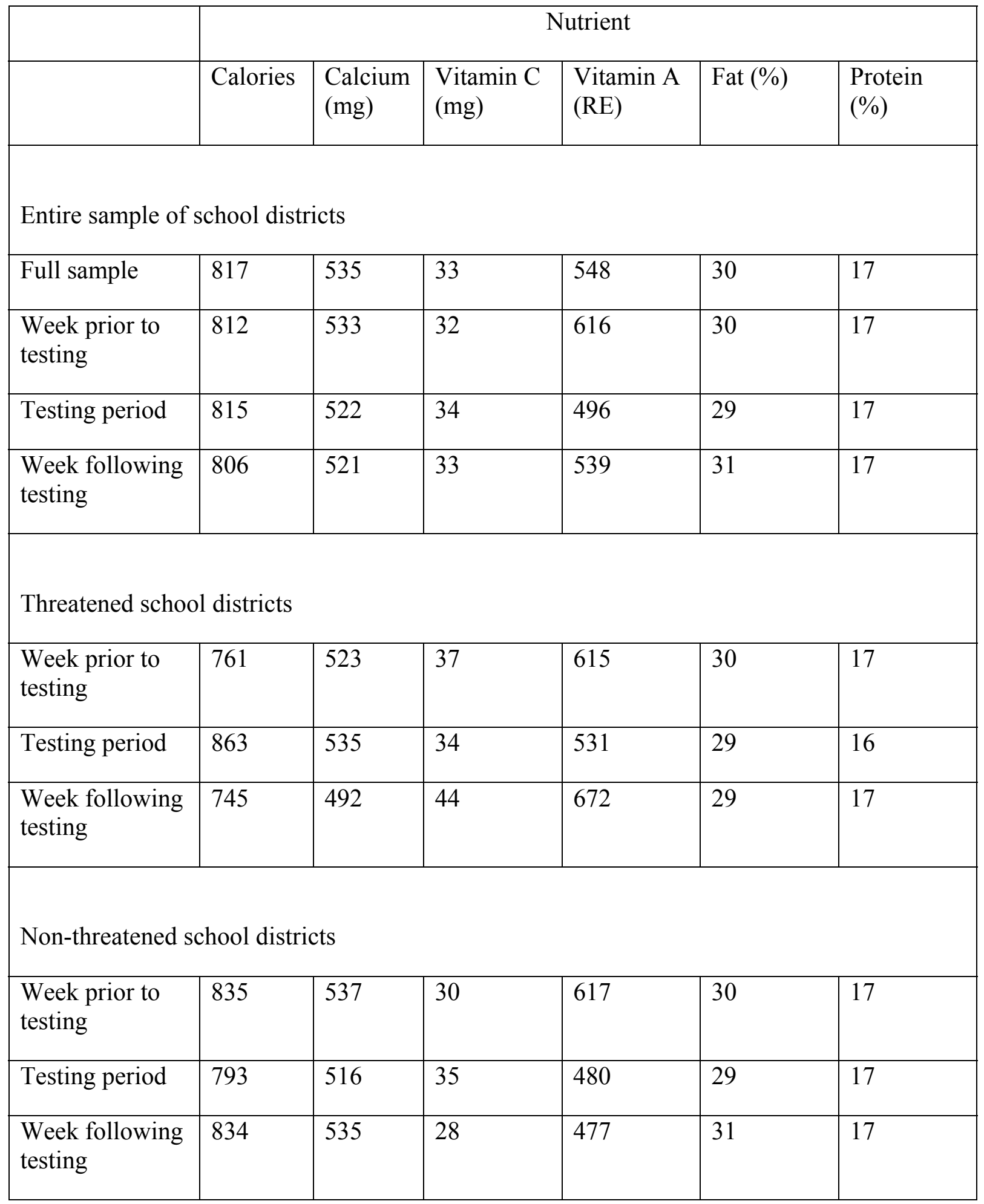


Table 3: Fixed effects regressions (robust standard errors): Effects of testing on school nutrition

\begin{tabular}{|l|c|c|c|c|c|c|}
\hline & \multicolumn{5}{|c|}{ Nutrient } \\
\hline $\begin{array}{l}\text { Coefficient } \\
\text { estimate }\end{array}$ & Calories & $\begin{array}{l}\text { Calcium } \\
(\mathrm{mg})\end{array}$ & $\begin{array}{l}\text { Vitamin C } \\
(\mathrm{mg})\end{array}$ & $\begin{array}{l}\text { Vitamin A } \\
(\mathrm{RE})\end{array}$ & Fat (\%) & $\begin{array}{l}\text { Protein } \\
(\%)\end{array}$ \\
\hline Specification I: No differentiation between threatened and non-threatened schools \\
\hline Testing period & -3.25 & -11.13 & 1.04 & -96.62 & -0.90 & -0.03 \\
& $(23.19)$ & $(21.44)$ & $(2.97)$ & $(76.24)$ & $(0.92)$ & $(0.41)$ \\
\hline Specification II: Differentiating between threatened and non-threatened schools \\
\hline Testing period & -47.03 & -26.24 & 4.86 & -82.63 & -1.09 & 0.38 \\
& $(27.66)$ & $(25.87)$ & $(3.58)$ & $(92.14)$ & $(1.12)$ & $(0.50)$ \\
\hline $\begin{array}{l}\text { Testing period x } \\
\text { threatened } \\
\text { school }\end{array}$ & 139.76 & 48.22 & -12.04 & -44.64 & 0.59 & -1.33 \\
\hline
\end{tabular}


Table 4: Sensitivity testing: Estimated effects of "false test weeks" on caloric composition of school lunches

\begin{tabular}{|c|c|c|}
\hline $\begin{array}{l}\text { Testing period assumed to be } \\
\text { during the week of: }\end{array}$ & $\begin{array}{l}\text { Coefficient estimate on } \\
\text { "testing period" }\end{array}$ & $\begin{array}{l}\text { Coefficient estimate on } \\
\text { "testing period" } \mathrm{x} \text { threatened } \\
\text { school }\end{array}$ \\
\hline February 7, 2000 & $\begin{array}{l}-10.98 \\
(29.03)\end{array}$ & $\begin{array}{l}41.59 \\
(54.58)\end{array}$ \\
\hline February 14, 2000 & $\begin{array}{l}-27.59 \\
(28.84)\end{array}$ & $\begin{array}{l}-21.74 \\
(53.22)\end{array}$ \\
\hline February 21, 2000 & $\begin{array}{l}-37.77 \\
(28.32)\end{array}$ & $\begin{array}{l}59.59 \\
(52.05)\end{array}$ \\
\hline February 28, 2000 & $\begin{array}{c}0.88 \\
(28.57)\end{array}$ & $\begin{array}{l}-44.68 \\
(52.10)\end{array}$ \\
\hline $\begin{array}{l}\text { March 6, } 2000 \\
\text { (actual testing period) }\end{array}$ & $\begin{array}{l}-47.03 \\
(27.66)\end{array}$ & $\begin{array}{l}139.76 \\
(49.42)\end{array}$ \\
\hline March 13, 2000 & $\begin{array}{l}-12.26 \\
(27.21)\end{array}$ & $\begin{array}{l}-48.53 \\
(48.04)\end{array}$ \\
\hline March 20, 2000 & $\begin{array}{l}10.45 \\
(24.8)\end{array}$ & $\begin{array}{c}1.02 \\
(44.36)\end{array}$ \\
\hline
\end{tabular}


Table 5: Sensitivity testing: Effects of excluding individual school districts on the estimated effects of testing on caloric composition of school lunches (only interaction term between testing period and threatened school reported in table)

\begin{tabular}{|c|c|c|c|}
\hline $\begin{array}{l}\text { Excluded district } \\
\text { number }\end{array}$ & $\begin{array}{l}\text { Coefficient estimate } \\
\text { on "testing period" } \mathrm{x} \\
\text { threatened school }\end{array}$ & $\begin{array}{l}\text { Excluded district } \\
\text { number }\end{array}$ & $\begin{array}{l}\text { Coefficient estimate } \\
\text { on "testing period" } \mathrm{x} \\
\text { threatened school }\end{array}$ \\
\hline 1 & $\begin{array}{l}120.93 \\
(52.92)\end{array}$ & 13 & $\begin{array}{l}131.67 \\
(51.65)\end{array}$ \\
\hline 2 & $\begin{array}{l}148.16 \\
(49.47)\end{array}$ & 14 & $\begin{array}{l}158.04 \\
(52.45)\end{array}$ \\
\hline 3 & $\begin{array}{l}139.68 \\
(52.77)\end{array}$ & 15 & $\begin{array}{l}151.96 \\
(49.89)\end{array}$ \\
\hline 4 & $\begin{array}{l}140.34 \\
(50.28)\end{array}$ & 16 & $\begin{array}{l}130.01 \\
(52.88)\end{array}$ \\
\hline 5 & $\begin{array}{l}135.32 \\
(48.77)\end{array}$ & 17 & $\begin{array}{l}134.63 \\
(49.82)\end{array}$ \\
\hline 6 & $\begin{array}{l}138.65 \\
(49.37)\end{array}$ & 18 & $\begin{array}{l}135.40 \\
(50.75)\end{array}$ \\
\hline 7 & $\begin{array}{l}144.59 \\
(50.03)\end{array}$ & 19 & $\begin{array}{l}141.63 \\
(50.46)\end{array}$ \\
\hline 8 & $\begin{array}{l}123.25 \\
(49.58)\end{array}$ & 20 & $\begin{array}{l}132.00 \\
(46.56)\end{array}$ \\
\hline 9 & $\begin{array}{l}153.02 \\
(52.27)\end{array}$ & 21 & $\begin{array}{l}136.92 \\
(50.28)\end{array}$ \\
\hline 10 & $\begin{array}{l}138.03 \\
(50.50)\end{array}$ & 22 & $\begin{array}{l}140.39 \\
(50.90)\end{array}$ \\
\hline 11 & $\begin{array}{l}141.57 \\
(50.04)\end{array}$ & 23 & $\begin{array}{l}144.88 \\
(52.65)\end{array}$ \\
\hline 12 & $\begin{array}{l}153.50 \\
(49.77)\end{array}$ & & \\
\hline
\end{tabular}


Table 6: Estimated effect on pass rate of increasing calorie differential (test days versus surrounding days) by 100 calories - school districts threatened with sanctions

\begin{tabular}{|l|l|}
\hline Fifth grade test & $\begin{array}{l}\text { Estimated effect of 100 point calorie } \\
\text { differential on pass rates }\end{array}$ \\
\hline Mathematics & 11.1 \\
& $(3.3)$ \\
\hline English & 5.8 \\
& $(3.3)$ \\
\hline Science & 1.6 \\
& $(3.1)$ \\
\hline History/social studies & 6.1 \\
& $(3.9)$ \\
\hline Writing & 2.0 \\
\end{tabular}

